\title{
Flexural Strength Analysis of Concrete With the Addition B3 Waste as an Additive to Ordinary Portland Cement
}

\author{
Norma Puspita ${ }^{1, *}$ Yuni Arti $^{1}$ Febryandi $^{1}$ \\ ${ }^{1}$ Civil Engineering Department, Indo Global Mandiri University \\ *Corresponding author.Email: norma.puspita@uigm.ac.id
}

\begin{abstract}
As generally known that concrete has low resistance to acidic and corrosive materials which usually exist in acidic and saline environment. And along the increasing of environment conservation, specifically about reusing a waste which is residue of an activity and/or a production process of industries such as metallic, mining, chemical, etc., that pollute the living environment without proper treatment as known as B3 wastes. Among materials belong to B3 waste category are Ground Granulate Blast Furnace Slag (GGBFS) and Fly Ash (FA). The objective of this study is to use GGBFS and FS as an additive and replacement materials of cement and to find the effect of these material to flexural strength of cement. This study uses a beam-shaped specimen with 10 mixed variations consisting of normal concrete $(0 \%)$, BFG $(2 \%, 2 \%)$, BFG $(2 \%, 4 \%)$, BFG $(2 \%, 6 \%)$, BFG $(4 \%, 2 \%)$, BFG $(4 \%, 4 \%)$, BFG $(4 \%, 6 \%)$, BFG (6\%, $2 \%)$, BFG $(6 \%, 4 \%)$, BFG $(6 \%, 6 \%)$ of cement weight. The results of flexural strength testing show that the mix variation of FA and GGBFS will be increase the average flexural strength of concrete than normal concrete without partial replacement of cement, and the optimum flexural strength had resulted by maximum addition of GGBFS content. Based on that, the material which is more preferable as partial replacement of OPC is GGBFS.
\end{abstract}

Keywords: acidic environment, flexural strength, B3 waste, Fly Ash, GGBFS

\section{INTRODUCTION}

Concrete is a construction that is commonly used by anyone. Concrete can be made by mixing ingredients such as water, coarse aggregates, fine aggregates, cement, and other mixed materials as needed. The more compact the concrete, the less cavity that will be produced so that concrete will not occur porous and concrete that will be produced can have high strength and low water absorption. As generally known that concrete has low resistance to acidic and corrosive materials which usually exist in acidic and saline environment. [1][2][3]

And along the increasing of environment conservation awareness, specifically about reusing a waste which is residue of an activity and/or a production process of industries such as metallic, mining, chemical, etc., that pollute the living environment without proper treatment as known as B3 wastes. Among materials belong to B3 waste category are Ground Granulate Blast Furnace Slag (GGBFS) and Fly Ash (FA).
GGBFS is the residue of combustion in the furnace of the steel refining process or by products of steel plant that has been finely ground which has cementitious properties like cement that can serve as an adhesive aggregate. GGBFS forming elements are lime, silica and alumina has a chemical composition that does not different from natural mineral material such as Portland Cement hydration, the analysis of physical chemistry of GGBFS showed in Table 1. A good fineness of GGBFS has the same adhesive strength quality such as Portland Cement.[4] While FA is the residue from burning coal in power plant which generally captured by particle filtration equipment of the coal-fired chimney before the exhaust gas reaches it. FA does not have the ability to bind particles or aggregates like cement, but with the fines size and presences of water in mix design, then $\mathrm{SiO}_{2}$ contained in FA will react chemically with $\mathrm{Ca}(\mathrm{OH})_{2}$ which formed by hydration process of cement and produces a substance that has bind ability. [5]

Due to characteristics of both materials, many research by scientists had been developed and found 
many benefit of those material for substitute or partial replacement of cement such environmental friendly (due to reusing a waste material), increasing resistance to sulphate / chloride [6]-[10], reducing bleed rates [11], increasing compressive strength [2], [8], [12]-[15], increasing durability [8], [13], [16], and reducing permeability of concrete [8].

Palembang city lied on Lowland area with most of areas has acidic environment which has special challenges to find special material for concrete construction. Based on previous research/studies of scientists, mostly studied the effect of GGBFS and FA to compressive strength of concrete which is studied only one material like only GGBFS or only FA to compressive strength. Based on it, the objective of this research is to analysis the effects of mix material (GGBFS + FA) as additive or partial replacement of cement to flexural strength of concrete in acidic environment. The acidic environment will be represented by curing with swampy water.

Table 1. Specification and Analysis of GGBFS Physical Chemistry

\begin{tabular}{|c|c|c|c|c|c|}
\hline \multirow{2}{*}{ No } & \multirow{2}{*}{ Parameter } & \multirow{2}{*}{ Oxide } & \multirow{2}{*}{ Result } & Lh & \multirow{2}{*}{ Referen PTSI } \\
\hline & & & & $(\mathrm{ppm})$ & \\
\hline 1 & Calium Oxide & $\mathrm{CaO}$ & $45,2 \%$ & - & \multirow{10}{*}{$(\mathrm{CaO}+\mathrm{MgO}+\mathrm{SiO} 2)>65 \%$} \\
\hline 2 & Silicone Oxide & $\mathrm{SiO}_{2}$ & $34,80 \%$ & - & \\
\hline 3 & Alumunium Oxide & $\mathrm{Al}_{2} \mathrm{O}_{3}$ & $14,79 \%$ & - & \\
\hline 4 & Sulphur Oxide & $\mathrm{SO}_{3}$ & $1,74 \%$ & - & \\
\hline 5 & Ferri Oxide & $\mathrm{Fe}_{2} \mathrm{O}_{3}$ & $1,34 \%$ & - & \\
\hline 6 & Magnesium Oxide & $\mathrm{MgO}$ & $0,99 \%$ & - & \\
\hline 7 & Titanium Oxide & $\mathrm{TiO}_{2}$ & $0,55 \%$ & - & \\
\hline 8 & Calium Oxide & $\mathrm{K}_{2} \mathrm{O}$ & $0,38 \%$ & - & \\
\hline 9 & Mangan Oxide & $\mathrm{MnO}$ & $0,25 \%$ & - & \\
\hline 10 & Natrium Oxide & $\mathrm{Na}_{2} \mathrm{O}$ & $0,22 \%$ & - & \\
\hline 11 & Barium Oxide & $\mathrm{BaO}$ & $0,08 \%$ & - & \\
\hline 12 & Phospor Oxide & $\mathrm{P}_{2} \mathrm{O}_{5}$ & $0,05 \%$ & - & \\
\hline 13 & Stronsium Oxide & $\mathrm{SrO}$ & $0,04 \%$ & - & \\
\hline 14 & Zirconium Oxide & $\mathrm{ZrO}_{2}$ & $0,04 \%$ & - & \\
\hline 15 & Chromium Oxide & $\mathrm{Cr}_{2} \mathrm{O}_{3}$ & $0,01 \%$ & $<250(0.025 \%)$ & \\
\hline 16 & Zinc Oxide & $\mathrm{ZnO}$ & $30 \mathrm{ppm}$ & $<500(0.050 \%)$ & \\
\hline \multicolumn{6}{|c|}{ Physic testing } \\
\hline NO & Parameter & Result & Unit & - & Referen PTSI \\
\hline 17 & Work Index & 21,68 & $\mathrm{kWh} / \mathrm{ton}$ & - & \\
\hline 18 & Weight Volume (fresh) & 1,106 & $\mathrm{~kg} / \mathrm{litre}$ & - & - \\
\hline 19 & Weight Volume (powder) & 0,963 & $\mathrm{~kg} / \mathrm{litre}$ & - & - \\
\hline 20 & Water level & 4 & $\%$ & & $<15 \%$ \\
\hline \multirow[t]{4}{*}{21} & BFS Fresh sifter analyze (Mesh) & & & & \\
\hline & No. $16(1180 \mu \mathrm{m})$ Passing: $80.43 \%$ & & & & $>75 \%$ \\
\hline & No. $30(600 \mu \mathrm{m})$ Passing: $41.72 \%$ & & & & \\
\hline & No. $50(300 \mu \mathrm{m})$ Passing: $11.92 \%$ & & & & \\
\hline
\end{tabular}

Source: Krakatau Steel Indonesia,

\section{RESEARCH METHOD}

\subsection{Research Site}

This research has done in Laboratory of PT Waskita Karya Jakabaring 3 Concrete Precast. The testing was done based on Indonesia National standard (SNI).

\subsection{Materials}

The main materials was using in this research which are Ground Granulated Blast Furnace Slag (GGBFS) from PT. Krakatau Steel Indonesia (Persero),Tbk., and Fly Ash (FA) from PT. Bukit Asam, Tbk.

\subsection{Design Formulas}

Mix design of this research has formulated in 10 variations which are used combined materials GGBFS and FA (showed in Table 2). 
Table 2. Design Formulas of Research

\begin{tabular}{|l|c|}
\hline Variation of Design Formulas & Sample Code \\
\hline $\mathrm{BN}$ & $\mathrm{C} 0$ \\
\hline $\mathrm{BFG}(2 \% *, 2 \% * *)$ & $\mathrm{C} 1$ \\
\hline $\mathrm{BFG}(2 \%, 4 \%)$ & $\mathrm{C} 2$ \\
\hline $\mathrm{BFG}(2 \%, 6 \%)$ & $\mathrm{C} 3$ \\
\hline $\mathrm{BFG}(4 \%, 2 \%)$ & $\mathrm{C} 4$ \\
\hline $\mathrm{BFG}(4 \%, 4 \%)$ & $\mathrm{C} 5$ \\
\hline $\mathrm{BFG}(4 \%, 6 \%)$ & $\mathrm{C} 6$ \\
\hline $\mathrm{BFG}(6 \%, 2 \%)$ & $\mathrm{C} 7$ \\
\hline $\mathrm{BFG}(6 \%, 4 \%)$ & $\mathrm{C} 8$ \\
\hline $\mathrm{BFG}(6 \%, 6 \%)$ & $\mathrm{C} 9$ \\
\hline
\end{tabular}

Note:

$\mathrm{BFG}=$ Beton $\mathrm{FA}$ dan GGBFS $=\mathrm{FA}$ and GGBFS Concrete

$\begin{array}{ll}* & \text { Fly Ash Percentage } \\ * * & \text { GGBFS Percentage }\end{array}$

\subsection{Research Procedures}

The methodology of research is shown in Figure 1.

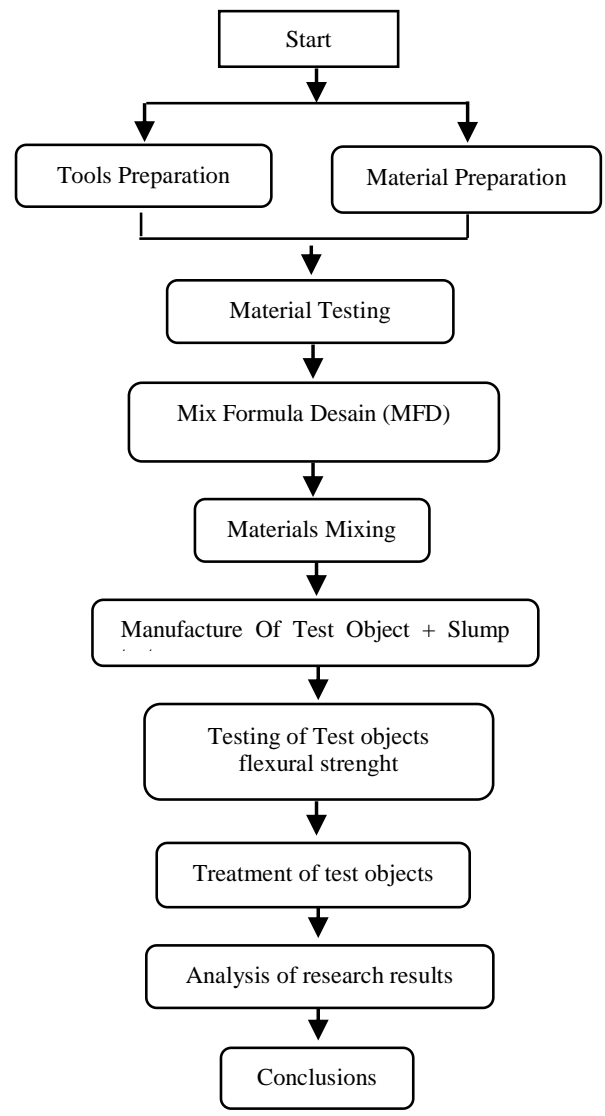

Figure 1. Procedure of Research

\subsubsection{Start}

This research started by finding problems of concrete and literature reviews related to research topic specially about flexural strength of concrete, GGBFS, and Fly Ash.

\subsubsection{Tools and material preparation}

Carry out the preparation of tools and material used to conduct research in the laboratory, such as Fly Ash, GGBFS, fine aggregate, coarse aggregate, OPC cement, peat water, block molds, pans, scales, a set of aggragate inspection tools, mixers, slump tools, machines fluxural strength test, etc.

\subsubsection{Matrials testing}

Testing of tools and materials for coarse aggragete and fine aggragate.

- Sieve analysis of fine aggregate and coarse aggregate.

- Levels of sludge contained in fine and coarse aggregates.

- Specific gravity and water absorption contained in fine aggregate and coarse aggregate.

- Organic content contained in fine aggregate while in coarse aggregate is absent.

- Moisture content contained in fine aggregate and coarse aggregate.

- Volume weight contained in fine aggregate and coarse aggregate.

\subsubsection{Mix formula design (MFG)}

Make a mix design plan from the results of material testing to making test object.

\subsubsection{Materials mixing}

Mixing materials such as cement, fine aggregate, coarse aggregate, Fly Ash water and GGBFS.

\subsubsection{Manufacture of test object + slump test}

Making of specimens using added materials of Fly Ash and GGBFS of $2 \%, 4 \%$ and $6 \%$ of normal concrete $(0 \%)$. The test object is in the form of a block of size $(15 \times 15 \times 60) \mathrm{cm}$ with a concrete age of 7,14 , and 28 days respectively, 3 samples of the specimen are then tested for slump to determine the thickness of the concrete.

\subsubsection{Testing of Test objects flexural strenght}

The flexural strength test of concrete is carried out to determine the results of the rise or fall of normal concrete before or after adding Fly Ash and GGBFS added materials for the life of the concrete 7,14 , and 28 days. 


\subsubsection{Treatment of test objects}

Treatment of hardened specimens and then immersed in peat water from the age of 7, 14 and 28 days.

\subsubsection{Analysis of research results}

Testing and analyzing data on the results of the concrete flexural strength test to see the development of each concrete age, the flexural strength based on additives, and the effects that occur in the test object during the immersion period in peat water.

\subsubsection{Conclusions}

From the test results, conclusions have been analysed about the effect of Fly Ash and GGBFS on OPC cement, the effect of using peat water for immersion in concrete and the percentage of optimum levels of Fly Ash and GGBFS from normal concrete.

\section{RESULT}

\subsection{Water Curing Contents}

In this research, water for curing treatment of concrete was using the water from swampy (peat) water as represent acidic environment. The result of chemical analysis of water was showed that has low $\mathrm{pH}$ and high sulfate (Table 3).

Table 3. Curing Water Contents

\begin{tabular}{|l|c|c|}
\hline \multicolumn{1}{|c|}{ Characteristics } & Unit & Result \\
\hline A. Physical \\
\hline Temperature & 0C & 24.5 \\
\hline Total Dissolve Solid (TDS) & $\mathrm{mg} / \mathrm{L}$ & 3810 \\
\hline Turbidity & $\mathrm{NTU}$ & 137.9 \\
\hline Color & $\mathrm{TCU}$ & 20 \\
\hline B. Chemical & - & 3.72 \\
\hline $\mathrm{pH}$ & $\mathrm{mg} / \mathrm{L}$ & 13200 \\
\hline Sulfate $(\mathrm{So} 4)$ & $\mathrm{mg} / \mathrm{L}$ & 29.78 \\
\hline Chloride $(\mathrm{Cl})$ & $\mathrm{mg} / \mathrm{L}$ & 34.5 \\
\hline Calsium $(\mathrm{Ca})$ & $\mathrm{mg} / \mathrm{L}$ & 3.77 \\
\hline Magnesium $(\mathrm{Mg})$ & $\mathrm{mg} / \mathrm{L}$ & 1962.53 \\
\hline Iron $(\mathrm{Fe})$ & $\mathrm{mg} / \mathrm{L}$ & 0.027 \\
\hline Manganese $(\mathrm{Mn})$ &
\end{tabular}

Source: Laboratory analysis, 2019.

\subsection{ANALYSIS OF FLEXURAL STRENGTH TO VARIATION DESIGN MATERIALS}

The analysis of flexural strength in this research in two scenarios, that are:

1. Analysis flexural strength with the constant of FA contents and variation of GGBFS contents $(2 \%, 4 \%$, $6 \%)$
2. Analysis flexural Strength with the constant of GGBFS contents and variation of FA contents (2\%, $4 \%, 6 \%)$.

3. Analysis flexural strength with compared all of variation designs

In scenario 1, the analysis result has showed that the magnitude of flexural strength of concrete in each of sample $(\mathrm{C} 1, \mathrm{C} 2, \mathrm{C} 3)$ when in early ages have flexural strength below normal concrete (C0), but will be increase strength along the age with flexural strength above $\mathrm{C}$, as showed by Graph in Figured 2. That graph also showed that the maximum flexural strength occurred at C3 sample with $3.91 \mathrm{MPa}$ which has the large contents of GGBFS $6 \%$.

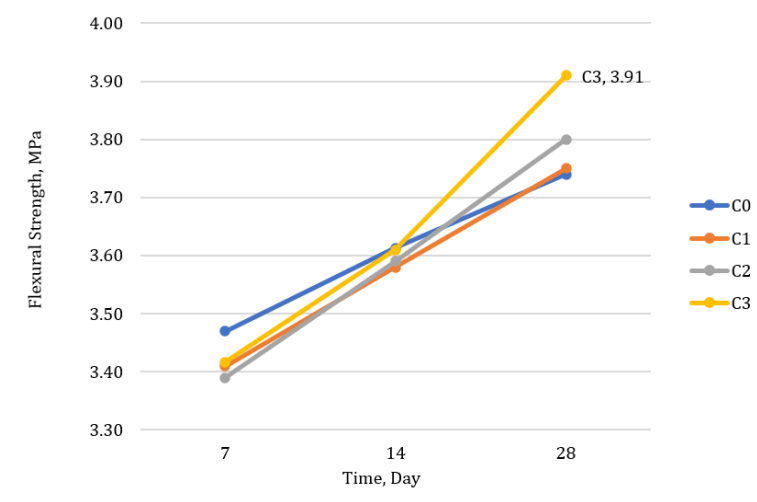

Figure 2. Flexural Strength Graph of Variation GGBFS as Cement Replacement with Fly Ash $2 \%$

Meanwhile in Scenario II, the analysis result has showed that the flexural strength of concrete in each sample $(\mathrm{C} 1, \mathrm{C} 4, \mathrm{C} 7)$ when in early age of concrete showed the same condition with scenario 1 that is below strength of normal concrete $(\mathrm{C} 0)$, but will be increase along the age of concrete. The difference result with scenario 1 that is although has increase strength but in the final age (day 28), C4 and C7 have flexural strength below $\mathrm{C} 0$, only $\mathrm{C} 1$ has slightly higher ( $3.75 \mathrm{MPa}$ ) than $\mathrm{C} 0$, it showed in Figure 3. It means that the decreasing of flexural strength of concrete was influenced by FA contents.

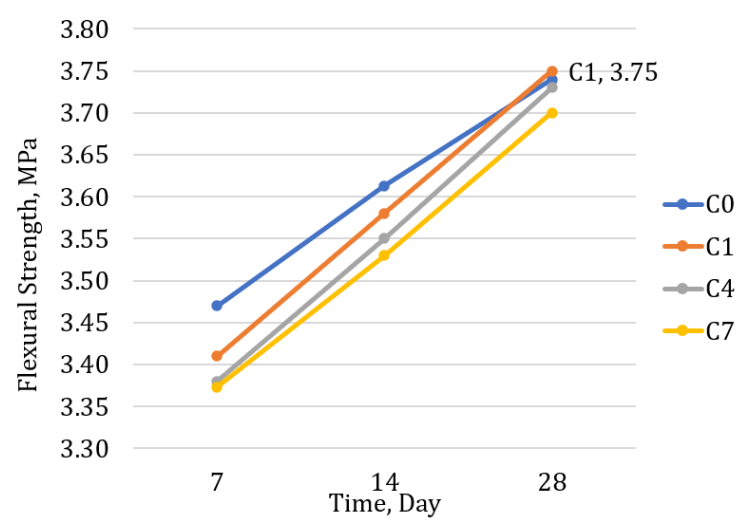

Figure 3. Flexural Strength Graph of Variation Fly Ash as Cement Replacement with GGBFS $2 \%$ 
Table 4. Recapitulation of concrete flexural strength based on concrete age.

\begin{tabular}{|c|c|c|c|c|c|c|c|c|}
\hline Mix Designs & $\begin{array}{c}\text { Age } \\
\text { (Day) }\end{array}$ & $\begin{array}{c}\text { Flexural } \\
\text { Strength } \\
(\mathrm{MPa})\end{array}$ & Mix Designs & $\begin{array}{l}\text { Age } \\
\text { (Day) }\end{array}$ & $\begin{array}{c}\text { Flexural } \\
\text { Strength } \\
(\mathrm{MPa})\end{array}$ & Mix Designs & $\begin{array}{c}\text { Age } \\
\text { (Day) }\end{array}$ & $\begin{array}{c}\text { Flexural } \\
\text { Strength } \\
(\mathrm{MPa})\end{array}$ \\
\hline \multirow{3}{*}{$\mathrm{BN}$} & 7 & 3.47 & & & & & & \\
\hline & 14 & 3.61 & & & & & & \\
\hline & 28 & 3.74 & & & & & & \\
\hline \multirow{3}{*}{$\mathrm{BFG}(2 \%, 2 \%)$} & 7 & 3.41 & \multirow{3}{*}{$\mathrm{BFG}(4 \%, 2 \%)$} & 7 & 3.38 & \multirow{3}{*}{$\mathrm{BFG}(6 \%, 2 \%)$} & 7 & 3.37 \\
\hline & 14 & 3.58 & & 14 & 3.55 & & 14 & 3.5 \\
\hline & 28 & 3.75 & & 28 & 3.73 & & 28 & 3.7 \\
\hline \multirow{3}{*}{$\mathrm{BFG}(2 \%, 4 \%)$} & 7 & 3.39 & \multirow{3}{*}{$\mathrm{BFG}(4 \%, 4 \%)$} & 7 & 3.37 & \multirow{3}{*}{$\mathrm{BFG}(6 \%, 4 \%)$} & 7 & 3.36 \\
\hline & 14 & 3.59 & & 14 & 3.58 & & 14 & 3.73 \\
\hline & 28 & 3.8 & & 28 & 3.76 & & 28 & 3.73 \\
\hline \multirow{3}{*}{$\mathrm{BFG}(2 \%, 6 \%)$} & 7 & 3.59 & \multirow{3}{*}{$\mathrm{BFG}(4 \%, 6 \%)$} & 7 & 3.42 & \multirow{3}{*}{$\mathrm{BFG}(6 \%, 6 \%)$} & 7 & 3.38 \\
\hline & 14 & 3.78 & & 14 & 3.6 & & 14 & 3.58 \\
\hline & 28 & 3.94 & & 28 & 3.9 & & 28 & 3.82 \\
\hline
\end{tabular}

Source: Laboratory Testing, 2019.

Scenario 3 has analysed based on Table 4 which showed that in early age of concrete have flexural strength below normal concrete strength for all of variation design, it showed in Figure 4. The graph in Figured 4 is showed that the magnitude flexural strength is significantly influenced by the amount of material replacement of cement. It also showed that maximum flexural strength is occurred in C3 with $3.91 \mathrm{MPa}$, followed by C6 $3.90 \mathrm{MPa}$, and C9 $3.82 \mathrm{MPa}$. Those sample have GGBFS contents larger than others sample.

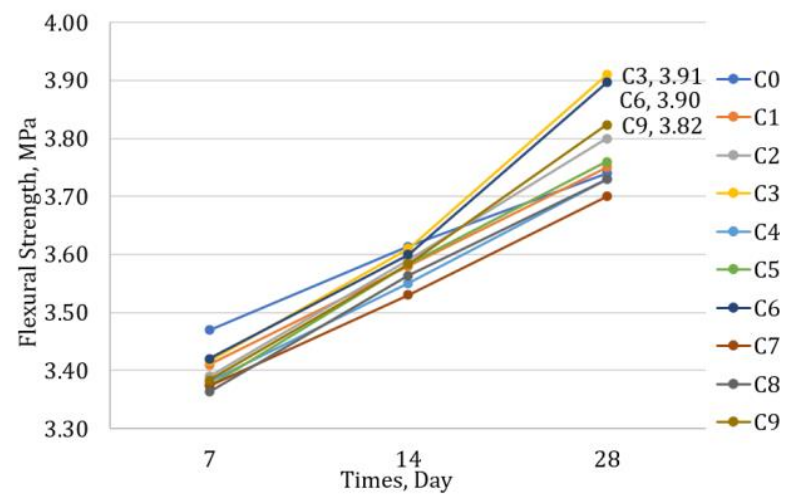

Figured 4. Flexural Strength Graph of Variation Fly Ash and GGBFS as Cement

\section{CONCLUSION}

Based on 3 scenarios analysis, this research has concluded:

1. The addition of Fly Ash and GGBFS additives as replacement of cement can increase the average flexure strength of concrete than Normal concrete.
2. The flexural strength is significantly influenced by type of additive materials and the amount of replacement material of cement

3. The more contents of FA than GGBFS will be affected magnitude of flexural strength which became fall down to below normal concrete strength.

4. Otherwise, the more content of GGBFS than FA will be increase the flexural strength above normal concrete strength.

5. The optimum flexural strength had resulted by maximum addition of GGBFS content (BFG $(2 \%, 6 \%)$; BFG $(4 \%, 6 \%)$; BFG $(6 \%, 6 \%))$ as partial replacement of OPC

6. The GGBFS material is more preferable than Fly ash as partial replacement material of OPC

\section{AUTHORS' CONTRIBUTIONS}

Author 1: Norma Puspita

- Conceived and designed the analysis

- Contributed data or analysis tools

- $\quad$ Performed the analysis

- Wrote the paper

Author 2: Yuni Arti

- $\quad$ Collected the data

Author 3: Febryandi

- Collected the data 


\section{ACKNOWLEDGMENTS}

The author would like to thank PT. Waskita Beton Precast, Jakabaring III Palembang which has permitted and assisted in the implementation of testing in the laboratory. And also for PT. PLTU Bukit Asam and PT. Krakatau Semen Indonesia which has provided research material in the form of Fly Ash and GGBFS.

\section{REFERENCES}

[1] K. J. Taku, D. Y. Amartey, and T. Kassar, "Effect of acidic curing environment on the strength and durability of concrete," Civ. Environ. Res., vol. 7, no. 12, pp. 8-13, 2015.

[2] N. Puspita, A. I. Hani'A, and M. Fauzi, "The effect of Ground Granulated Blast Furnace Slag (GGBFS) on Portland cement type II to compressive strength of high quality concrete," IOP Conf. Ser. Mater. Sci. Eng., vol. 830, no. 2, 2020, doi: 10.1088/1757-899X/830/2/022068.

[3] J. J. Sokołowska and P. Woyciechowski, "Effect of acidic environments on cement concrete degradation," Sustain. Constr. Mater. Technol., vol. 2013-Augus, no. August 2013, 2013.

[4] I. Knowledgebase, "Blast Furnace Slag / Ground Granulated Blast Furnace Slag Ground Granulated Blast Furnace Slag Speci cations and Analysis of Results of GBFS Physical Chemistry," http//krakatausemenindonesia.com/en/BlastFur naceSLag, accessed December 5, 2020, 914 AM, pp. 3-5, 2020, [Online]. Available: http://krakatausemenindonesia.com/en/BlastFur naceSLag.

[5] O. Ortiz, F. Castells, and G. Sonnemann, "Sustainability in the construction industry: A review of recent developments based on LCA," Constr. Build. Mater., vol. 23, no. 1, pp. 28-39, 2009, doi: 10.1016/j.conbuildmat.2007.11.012.

[6] H.-W. Song, S.-J. Kwon, S.-W. Lee, and K.-J. Byun, "A Study on Resistance of Chloride Ion Penetration in Ground Granulated Blast-Furnace Slag Concrete," J. Korea Concr. Inst., vol. 15, no. 3, pp. 400-408, 2003, doi: 10.4334/jkci.2003.15.3.400.

[7] D. K. Ashish, B. Singh, and S. K. Verma, "The effect of attack of chloride and sulphate on ground granulated blast furnace slag concrete," Adv. Concr. Constr., vol. 4, no. 2, pp. 107-121, 2016, doi: 10.12989/acc.2016.4.2.107.
[8] M. C. Chi, J. H. Chi, and C. H. Wu, "Effect of GGBFS on Compressive Strength and Durability of Concrete," Adv. Mater. Res., vol. 1145, pp. 22-26, 2018, doi: 10.4028/www.scientific.net/amr.1145.22.

[9] J. H. Park, C. Park, S. H. Joh, and H. S. Lee, "Effect of curing condition on resistance to chloride ingress in concrete using ground granulated blast furnace slag," Materials (Basel)., vol. 12, no. 19, 2019, doi: $10.3390 / \mathrm{ma1} 193233$

[10] T. Lee and J. Lee, "Evaluation of chloride resistance of early-strength concrete using blended binder and polycarboxylate-based chemical admixture," Appl. Sci., vol. 10, no. 8, 2020, doi: 10.3390/APP10082972.

[11] P. J. Wainwright and N. Rey, "Wainwright, P., and Rey, N., " The influence of ground granulated blastfurnace slag (GGBS) additions and time delay on the bleeding of concrete'. Cement and Concrete Composites, 22(4), pp.253-257, 2000.," vol. 22, pp. 253-257, 2000.

[12] M. Shariq, J. Prasad, and A. Masood, "Effect of GGBFS on time dependent compressive strength of concrete," Constr. Build. Mater., vol 24, no. 8, pp. 1469-1478, 2010, doi: 10.1016/j.conbuildmat.2010.01.007.

[13] R. Vijaya Sarathy and G. Dhinakaran, "Strength and durability characteristics of GGBFS based HPC," Asian Journal of Applied Sciences, vol. 7, no. 4. pp. 224-231, 2014, doi: 10.3923/ajaps.2014.224.231.

[14] M. Chi, J.-J. Chang, and W. Yeih, "Physical and Mechanical Properties of Concrete with Circulated Fluidized Bed Combustion Fly Ash, Ground Granulated Blast Furnace Slag and Coal Fly Ash," no. Icadme, pp. 27-30, 2015, doi: 10.2991/icadme-15.2015.6.

[15] S. Choi and S. Pyo, "Fresh and hardened properties of portland cement-slag concrete activated using the by-product of the liquid crystal display manufacturing process,' Materials (Basel)., vol. 13, no. 19, pp. 1-15, 2020, doi: 10.3390/ma13194354.

[16] D. Sandy, L. Febriani, and S. R. Topana, "Combination of Silica Fume and Fly Ash in Concrete with Sulfuric Acid-Curing," Int. J. Eng. Sci. Appl., vol. 6, no. 1, pp. 15-19, 2019. 